\title{
ANALISIS PERSEPSI EMPLOYEE EMPOWERMENT TERHADAP EMPLOYEE TURNOVER INTENTION DI DEWI SINTA HOTEL
}

\author{
I Gede Sunarjaya dan Yudha Eka Nugraha \\ Email: gede_sunarjaya@pib.ac.id dan yudha.eka@pib.ac.id \\ POLITEKNIK INTERNASIONAL BALI
}

\begin{abstract}
ABSTRAK
Penelitian ini dilakukan untuk mengetahui pengaruh persepsi employee empowerment yang sudah dilakukan oleh Dewi Sinta Hotel kepada karyawan terhadap keinginan karyawan untuk keluar dari Dewi Sinta Hotel yang merupakan salah satu hotel berbintang 3 di Tabanan, Bali yang memiliki masalah turnover karyawan. Hasil penelitian menunjukkan bahwa persepsi employee empowerment karyawan berpengaruh secara simultan terhadap turnover intention. Namun secara parsial, terdapat 5 variabel dari persepsi employee empowerment yang berpengaruh secara signifikan terhadap turnover intention sedangkan 2 variabel lainnya tidak berpengaruh signifikan. Disisi lain, variabel yang paling dominan berpengaruh adalah meaningfulness.
\end{abstract}

Kata kunci: Persepsi, Employee Empowerment, Employee Turnover Intention

\section{ABSTRACT}

This present study aims to analyse the influence of employee's perception to the empowerment done by the company towards employee turnover intention. This research is going to analyze the influence of employee's perception to the empowerment that has been done by the company towards employee turnover intention. Dewi Sinta Hotel is one of the three stars hotels in Tabanan, Bali that has been identified with employee turnover problem. This study reveals that employee empowerment perception simultaneously gives influence on the employee turnover intention. However, from the seven variables of employee empowerment, there are only five variables which significantly influence the turnover intention; while the other two variables do not give a significant influence on the turnover intention. In addition, meaningfulness is the most dominant variable in giving influence on the employee turnover intention.

Keywords: Perception, Employee Empowerment, Employee Turnover Intention 


\section{Pendahuluan}

Pariwisata dinilai oleh banyak pihak memiliki arti penting sebagai salah satu alternatif pembangunan, terutama bagi negara atau daerah yang memiliki keterbatasan sumberdaya alam. Untuk memaksimumkan dampak positip dari pembangunan pariwisata dan sekaligus menekan serendah mungkin dampak negatip yang ditimbulkan, diperlukan perencanaan yang bersifat menyeluruh dan terpadu. Rencana pengembangan pariwisata diperlukan oleh berbagai pihak sebagai pedoman dalam mengembangkan aktivitas di bidang masing-masing. Bahkan, rencana pengembangan dimaksud harus bersinergi dengan rencana-rencana pembangunan pada sektor-sektor lain dan tetap konsisten dengan rencana pembangunan kepariwisataan nasional secara keseluruhan. Pariwisata merupakan kegiatan yang kompleks, bersifat multi sektoral dan terfragmentsikan, karena itu koordinasi antar berbagai sektor terkait melalui proses perencanaan yang tepat sangat penting artinya.

Perencanaan juga diharapkan dapat membantu tercapainya kesesuaian (match) antara ekspektasi pasar dengan produk wisata yang dikembangkan tanpa harus mengorbankan kepentingan masing-masing pihak. Mengingat masa depan penuh perubahan, maka perencanaan diharapkan dapat mengantisipasi perubahan-perubahan lingkungan strategis yang dimaksud dan menghindari sejauh mungkin dampak negatip yang ditimbulkan oleh perubahan perubahan lingkungan, salah satunya terkait dengan karyawan yang merupakan bagian vital dalam hotel.

Karyawan adalah aset yang sangat berharga bagi organisasi atau perusahaan. Sebagai aset, karyawan harus bisa dikelola dengan baik agar tetap bisa memberikan kontribusi kepada organisasi atau perusahaan. 
Menurut Handoko (2001:4) keberhasilan pengelolaan organisasi sangat ditentukan kegiatan pendayagunaan sumber daya manusia. Oleh karna itu, organisasi atau perusahaan dituntut untuk dapat mengelola sumber daya manusia atau karyawan yang dimiliki dengan baik demi kelangsungan hidup dan kemajuan organisasi atau perusahaan. Akan tetapi, mengolah sumber daya manusia atau karyawan bukanlah hal yang mudah, karena karyawan tidak dapat dan tidak boleh disamakan dengan alat atau mesin pabrik, masing-masing dari mereka memiliki pikiran, perasaan, status, keinginan, dan latar belakang yang berbeda antara yang satu dengan yang lain.

Karyawan berperan aktif dalam aktivitas perusahaan dalam hal mewujudkan tujuannya. Perusahaan secara umum bertujuan memenuhi keinginan pasar. Menurut Hariandja (2002: 312), secara sosial, pekerja merupakan aset masyarakat sebagai subyek dalam usaha meningkatkan kesejahteraan masyarakat dan dengan melakukan usaha-usaha untuk meningkatkan keselamatan kerja dan meningkatkan profesionalisme departemen Sumber Daya Manusia dalam mengelola produktivitas.

Menurut Baldrige (Abdul, 2005: 111) sumber daya manusia (SDM) merupakan kategori kelima dari kriteria Baldrige. Kategori ini menilai bagaimana sistem kerja, motivasi, dan pembelajaran pegawai dalam membangun kondisi yang memungkinkan pemberdayaan pegawai secara penuh dan selaras dengan tujuan serta rencana tindakan perusahaan secara menyeluruh. Dengan kata lain produktivitas yang maksimal oleh suatu perusahaan didukung dengan kesejahteraan karyawannnya. Banyak hal yang berhubungan dengan peningkatan produktivitas kerja karyawan dan salah satunya adalah pemberdayaan karyawan. 
Analisis Persepsi Employee Empowerment Terhadap Employee Turnover Intention Di Dewi Sinta Hotel

Pemberdayaan karyawan atau dalam istilah Bahasa inggris dikenal dengan sebutan Employee Empowerement merupakah salah satu pendekatan dalam pengelolaan sumber daya manusia yang efektif khususnya dalam industri jasa. Melihat fakta bahwa industri berbasis jasa selalu menekankan pada layanan yang dapat diandalkan, karyawan sebagai penyedia jasa diharapkan mampu memberikan respon yang cepat dan tepat terhadap kebutuhan pelanggan.

Employee Empowerment meliputi pembagian otoritas sampai dengan pengambilan keputusan kepada karyawan yang diberdayakan. Karyawan diberikan kebebasan dan wewenang dalam mengambil keputusan tertentu dan menyelesaikan persoalan yang dihadapi pada saat menyampaikan layanan kepada pelanggan tanpa campur tangan dari penyelia atau manajer. Perusahaan jasa saat ini seringkali menerapkan employee empowerment khususnya dalam hal penanganan keluhan pelanggan dan pada saat karyawan mengupayakan tercapainya kepuasan pelanggan dengan cara apapun demi tercapainya kepuasan pelanggan serta memberi solusi terhadap masalah yang dihadapi pelanggan. (Lashley, 2001).

Misalnya pada bisnis restoran, server seringkali diberikan empowerment untuk dapat memberikan pelayanan yang terbaik seperti: mengganti makanan dengan yang baru saat pelanggan mengeluhkan kualitas makanan yang disajikan dan bahkan terkadang memberikan complimentary berupa minuman gratis sebagai bentuk permohonan maaf dan mempertahankan kesetiaan pelanggan.

Berdasarkan sebuah penelitian yang pernah dilakukan terkait dengan employee empowerment mengindikasikan bahwa employee empowerment berdampak signifikan pada peningkatan perasaan karyawan dalam melakukan pekerjaannya sehingga dapat memfasilitasi 
meningkatnya komitmen dan mengurangi keinginan karyawan untuk keluar. (Mishra \& Spreitzer, 1998). Lebih jauh, Salazar (2000) melalui penelitiannya membuktikan adanya hubungan yang kuat antara employee empowerment dan organizational commitment. Dalam hal ini, karyawan peningkatan komitmen karyawan dapat terjadi bila diberdayakan secara tepat oleh perusahaan. Light (2004) melalui penelitian yang dilakukannya membuktikan bahwa terdapat hubungan yang kuat antara employee empowerment dengan employee satisfaction, selain itu hubungan yang kuat juga terjadi antara employee satisfaction terhadap loyalitas karyawan. Mengacu pada hasil penelitian tersebut, peneliti bermaksud melihat kemungkinan adanya hubungan antara penerapan employee empowerment dengan pengendalian turnover karyawan yang seringkali menjadi permasalahan yang dihadapi oleh organisasi terutama pada hospitality industry seperti misalnya hotel.

Turnover merupakan hal yang diperhatikan karena dapat mempengaruhi kondisi suatu perusahaan. Menurut Wirawan (2015), Turnover dapat diartikan sebagai keinginan untuk berpindah dari suatu pekerjaan ke pekerjaan lain dengan alasan tertentu. Jika keinginan berpindah dalam sebuah perusahaan tinggi maka akan menimbulkan beberapa efek negatif berupa ketidakstabilan dan kerancuan yang dapat merugikan perusahaan serta karyawan. Perusahaan akan menambah biaya khususnya dalam hal perekrutan sampai pelatihan calon karyawan baru agar kekosongan dapat terisi sehingga kegiatan produksi dapat berjalan normal. Jika perusahaan mengabaikan kekosongan tersebut, maka akan berimbas langsung kepada karyawannya.

Bertambahnya beban kerja dan faktor-faktor lainnya dapat menimbulkan stres dan ketidak nyamanan karyawan yang berakibat mengganggu kinerjanya. Jika hal tersebut terjadi terus menerus, maka 
keinginan untuk berpindah akan semakin kuat. Kardiman, dkk (2012) mengungkapkan turnover intention pada umumnya berdampak buruk terhadap organisasi, seringkali dibutuhkan oleh perusahaan yang memiliki karyawan dengan kinerja yang rendah atau untuk mencari beberapa ahli dibidangnya sehingga dapat meingkatkan produktivitas dan kinerja suatu perusahaan. Turnover bisa berdampak negatif dan positif bagi perusahaan.

Apabila sebuah perusahaan kehilangan 20\% karyawan yang berkinerja tinggi, maka dampak negatif juga akan dirasakan oleh perusahaan tersebut. Berdasarkan studi yang ada, karyawan dengan kontribusi tinggi memiliki signikansi hingga 10x lipat dibanding karyawan umum. Oleh sebab itu, menjaga turnover effect dari karyawan yang memiliki performa tinggi harus di bawah 5\% Tetapi jika perusahaan kehilangan orang yang dirasakannya mempunyai performance yang rendah sebanyak $20 \%$, hal tersebut tentu akan menimbulkan dampak positif terhadap perusahaan karena perusahan dapat menggantinya dengan orang yang lebih berkompeten (Sullivan, 2009).

Sejalan dengan Mello (2002), dengan adanya turnover perusahaan dapat memperkerjakan karyawan-karyawan baru yang membawa ide-ide baru yang mungkin dapat menjadi poin penting bagi perusahaan stagnant atau perusahaan yang memerlukan inovasi. Secara finansial dan waktu, persentase turnover yang besar akan sangat berpengaruh bahkan merugikan perusahaan (Handoyo, 1987). Dengan adanya turnover berarti perusahaan kehilangan sejumlah tenaga kerja dan harus diganti dengan karyawan baru.

Dari segi finansial, perusahaan harus mengeluarkan biaya mulai dari perekrutan hingga mendapatkan tenaga kerja siap pakai. Perlu dicatat bahwa karyawan baru juga membutuhkan waktu untuk beradaptasi 
dengan lingkungan baru. Selain mengalami kerugian dalam segi biaya dan waktu, turnover dapat berpengaruh juga terhadap kelangsungan operasional perusahaan. Selain itu, keberhasilan suatu perusahaan untuk mencapai tujuan bersama tidak bisa dipisahkan dari tingkat konsentrasi yang tinggi.

Jika manajemen disibukkan dengan keluar masuknya karyawan, hal ini akan mempengaruhi kinerja perusahaan secara keseluruhan. Perusahaan harus dapat mengendalikan tingkat turnover karyawan agar dapat menghemat biaya, waktu, dan tetap menjaga konsenterasi kelangsungan operasional perusahaan. Sullivan (2009) menyatakan sebuah perusahaan harus menjaga tingkat turnover karyawan dengan low performance agar tidak lebih dari $10 \%$. Sejalan dengan itu, Roseman (1981) dalam bukunya Managing Turnover menyatakan bahwa jika annual turnover di dalam suatu perusahaan melebihi angka 10\%, maka turnover di dalam perusahaan tersebut dapat dikategorikan tinggi.

Berdasarkan data yang diperoleh dari salah satu hotel berbintang 3 di Tabanan, Bali yaitu Hotel Dewi Sinta, rata-rata tingkat turnover selama tahun 2016 yang paling tertinggi berasal dari divisi Food \& Beverage Service yaitu sebesar $18,1 \%$, kemudian diikuti dengan divisi Front Office sebesar 15,38\%, serta 11,76\% dari pihak accounting. Dari data tersebut, dapat dilihat bahwa tingkat turnover karyawan di Dewi Sinta Hotel, Tabanan, Bali, cukup tinggi. Menurut Roseman (1981) jika annual turnover di dalam suatu perusahaan melebihi angka 10\%, maka turnover di dalam perusahaan tersebut dapat dikategorikan tinggi. Disisi lain, pihak Dewi Sinta Hotel telah menerapkan employee empowerment. Usaha ini pun belum menghasilkan signifikansi terhadap penurunan jumlah karyawan yang mengundurkan diri. Oleh karena itu, dilakukan penelitian berjudul Analisis Persepsi Employee Empowerment Terhadap 
Employee Turnover Intention di Dewi Sinta Hotel. Penelitian ini menjadi sangat penting untuk dilakukan karena menyangkut kelangsungan perusahaan dalam penelitian ini yaitu hotel.

Terkait dengan fenomena tersebut maka permasalahan yang akan diteliti sebagai berikut: 1) Apakah persepsi employee empowerment berpengaruh secara signifikan terhadap employee turnover intention di Dewi Sinta Hotel? 2) Apakah persepsi employee empowerment secara parsial berpengaruh signifikan terhadap employee turnover intention di Dewi Sinta Hotel? 3) Manakah variabel persepsi employee empowerment yang paling dominan berpengaruh terhadap employee turnover intention di Dewi Sinta Hotel?

\section{KONSEP DAN TEORI}

Pada bagian ini akan dipaparkan mengenai konsep dan teori yang digunakan dalam penelitian ini.

\subsection{PERSEPSI}

Menurut Nord dalam Gibson (1985: 56) persepsi adalah "proses pemberian arti (cognitive) terhadap lingkungan oleh seseorang. Lebih lanjut, Thoha (1997: 141-142) mengemukakan bahwa persepsi pada hakikatnya adalah proses kognitif yang dialami oleh setiap orang di dalam memproses informasi tentang lingkungannya melaluipenglihatan, pendengaran, penghayatan, perasaan, dan penciuman Sedangkan Robbins (1994) mengartikan persepsi sebagai suatu proses dengan mana individu mengorganisasikan dan menafsirkan kesan-kesan panca indera yang diterima dan diartikan terhadap lingkungan.

Sebuah persepsi yang timbul selalu diawali dengan adanya informasi tentang lingkungan yang ditangkap dengan panca indera kemudian dengan melibatkan proses kognitif dan keadaan 
emosional seseorang akan memberikan tanggap atau tindakan atas objek tersebut. Persepsi adalah proses memberi makna pada sensasi sehingga manusia memperoleh pengetahuan yang baru. Oleh karena itu, persepsi dapat disimpulkan sebagai proses individual yang berupa menerima, menilai informasi yang diterima melalui panca indera dan mengelola berdasarkan pengalaman pribadi

\subsection{EMPLOYEE EMPOWERMENT}

Menurut Stewart (1998) employee empowerment berarti memberi kesempatan kepada karyawan untuk merencanakan, melaksanakan, dan mengendalikan pekerjaan yang menjadi tanggung jawabnya atau kelompoknya. Sedangkan Luthans (1998) mendefinisikan empowerment sebagai wewenang dalam membuat keputusan dalam sebuah area pekerjaan tanpa membutuhkan persetujuan dari orang lain.

Secara umum Empowerment dapat dilihat dalam dua perspektif yaitu: relational perspective (organizational empowerment) dan psychological perspective (psychological empowerment). Relational empowerment melihat bahwa empowerment tercipta ketika tingkatan yang lebih tinggi dalam hirarki perusahaan membagi kekuasaannya kepada tingkatan yang lebih rendah. Sedangkan psychological perspective berfokus pada sebuah persepsi empowerment yang dimiliki oleh karyawan. Psychological empowerment merupakan variabel yang merefleksikan atau mencerminkan tingkatan empowerment yang dirasakan karyawan. (Spreitzer, 1997; Conger dan Kanungo, 1988)

\subsection{TURNOVER INTENTION}

Turnover intention pada dasarnya adalah keinginan karyawan untuk keluar dari satu tempat kerja dan pindah ke tempat kerja baru. Hal 
tersebut menunjukkan bahwa turnover intention adalah keinginan berpindah namun belum sampai pada tahap realisasi (Harnoto, 2002)

Intensi keluar seorang karyawan disebabkan oleh ketidakpuasan terhadap pekerjaan yang dapat memicu keinginan seseorang untuk keluar mencari pekerjaan yang baru. Selain mengganggu kelangsungan kinerja tingkat keluar masuk seorang karyawan juga mengakibatkan terganggunya kelangsungan dari sebuah proses produksi, bila tingkat intesi keluar karyawan sudah mencapai $2 \%$ ke atas, maka itu terbilang tinggi. Maka hal itu memerlukan penanganan yang serius dari perusahaan, sebab bila dibiarkan terus berlangsung, berakibat bukan hanya produksi saja terlebih lagi terhadap mental karyawan yang masih bertahan pada perusahaan. (Harnoto, 2002)

\subsection{TEORI TURNOVER INTENTION}

Menurut Lum et. al. (1998) dikatakan bahwa intensi keluar merupakan variabel yang paling berhubungan dan lebih banyak menjelaskan mengenai perilaku turnover. Dimana keinginan untuk keluar dapat diukur dengan 3 komponen berikut ini:

1. Keinginan untuk mencari pekerjaan baru dibidang yang sama di perusahaan lain. Melihat adanya perusahaan lain yang dirasa mampu memberikan keuntungan lebih banyak dibandingkan tempat dia bekerja saat ini, dapat menjadi alasan utama bagi individu untuk memicu keinginannya keluar dari perusahaan. Namun hal itu hanya akan terbatas pada saat akan menerima jika sesuai kemampuannya.

2. Keinginan untuk mencari pekerjaan baru dibidang yang berbeda di perusahaan lain. Seorang individu yang merasa selama ini kurang mengalami kemajuan pada pekerjaan akan mencoba untuk beralih pada bidang yang berbeda denga harapan akan memperoleh hasil atau 
pendapatan yang lebih baik. Keinginan untuk mencari profesi baru. Dengan memiliki keahlian yang cukup banyak, timbulnya keinginan mencari pekerjaan baru yang sebelumnya tidak pernah dia kerjakan akan lebih sering terjadi.

Hom dan Griffeth (1991) mengemukakan bahwa intensi keluar karyawan dapat diukur dengan mengembangkan pertanyaan sebagai berikut (dalam Panggabean, 2004: 141):

1. Adanya pemikiran untuk meninggalkan pekerjaan.

2. Karyawan telah mengevaluasi kerugian yang diakibatkan jika keluar dari pekerjaan.

3. Karyawan memiliki keinginan untuk keluar.

4. Karyawan memiliki kemungkinan untuk pindah pekerjaan pada waktu yang akan datang.

\section{METODE PENELITIAN}

Jenis penelitian ini adalah penelitian kuantitatif yang merupakan penelitian deskriptif kausal. Sampel yang diambil dalam penelitian ini adalah karyawan tetap yang bekerja di hotel Dewi Sinta dengan teknik pengambilan secara proporsional dari masing-masing departemen. Teknik pengambilan sampel adalah non-probability sampling dimana pada rancangan sampel non-probabilitas penarikan sampel tidak penuh dilakukan dengan menggunakan hukum probabilitas, artinya bahwa tidak semua unit populasi memiliki kesempatan untuk dijadikan sampel penelitian. Selain itu, juga ditentukan berdasarkan quota sampling, yaitu peneliti mengklasifikasikan populasi menurut kriteria tertentu, dalam penelitian ini populasi diklasifikasikan menurut departemen, kemudian proporsi sampel yang dikehendaki untuk tiap kelas ditentukan, setelah itu barulah ditentukan kuota untuk setiap klasifikasi. 
Berdasarkan perhitungan jumlah populasi 145 orang karyawan tetap, maka diperoleh minimal sampel yang diteliti adalah 105 orang karyawan tetap. Jumlah minimal sampel ini kemudian diambil secara proporsional dari tiap-tiap departemen. Dalam penelitian ini jenis data yang dikumpulkan untuk diolah dan dianalisa yaitu:

1) Data primer adalah data yang dikumpulkan langsung melalui obyeknya (sumber utama) yaitu karyawan tetap di tiap departemen yang bekerja di hotel Dewi Sinta, melalui daftar pertanyaan atau kuisioner

2) Data sekunder adalah data yang diperoleh dari: a) Internal data turnover dan jumlah karyawan hotel Dewi Sinta, b) Wawancara dengan pihak hotel Dewi Sinta untuk mengetahui employee empowerment yang telah dilakukan.

\section{GAMBARAN DEWI SINTA HOTEL}

Dewi Sinta Hotel berjarak hanya 5 menit jalan kaki dari Pura Tanah Lot dan Pura Batu Bolong. Hotel ini menawarkan kolam renang outdoor dan Wi-Fi gratis di area umumnya. Layanan pijat dan restoran juga turut tersedia di hotel ini. Dewi Sinta Hotel and Restaurant berjarak 40 menit jika berkendara dari Kuta, dan 45 menit berkendara ke Bandara Internasional Ngurah Rai. Minibar, fasilitas membuat teh/kopi, dan TV kabel adalah fasilitas standar di semua kamar. Kamar mandi dalamnya dilengkapi dengan perlengkapan mandi dan bathtub.

Hotel ini menawarkan pengaturan perjalanan wisata di meja layanan wisata, serta penjemputan bandara berdasarkan permintaan. Layanan binatu dan dry cleaning juga tersedia. Staf juga dapat membantu dengan pemesanan sesi bermain golf di lapangan golf di dekatnya. Para pelanggan dapat menikmati berbagai masakan lokal Indonesia di restoran 
hotel, yang juga menawarkan layanan kamar. Saat ini hotel Dewi Sinta cukup popular dengan memiliki skor 8,7 di booking.com.

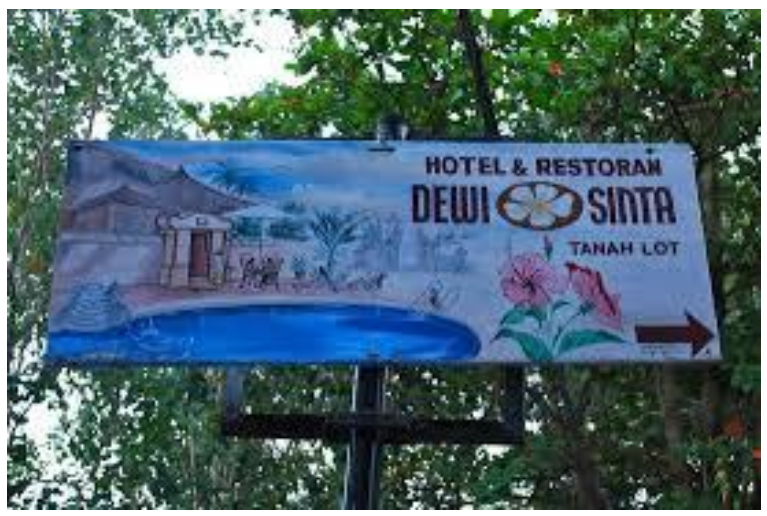

Gambar 1 Papan Nama Dewi Sinta Hotel

Sumber: https://www.tripadvisor.co.id/LocationPhotoDirectLinkg297697-d1650012-i61685100-Hotel_Dewi_Sinta-

\section{PEMBAHASAN}

pembahasan pada artikel ini terbagi menjadi tiga buah subbab penelitian yaitu Dewi Sinta Hotel, Employee Empowerment, dan TurnOver Intention. Berikut adalah masing-masing penjabarannya.

\subsection{EMPLOYEE EMPOWERMENT}

Pada employee empowerment, paling tidak terdapat tujuh buah komponen yang harus menjadi pokok pembahasan. Komponenkomponen tersebut antara lain: meaningfulness, competence, self determination, impact, dynamic structural framework, control of workplace decisions, dan fluidity in information sharing. Berikut adalah masing-masing penjabaran komponen tersebut.

a) Variabel Meaningfulness

Meaningfulness berarti pekerjaan yang dilakukan karyawan tersebut dirasakan bernilai atau bermakna oleh karyawan berdasarkan 
ideal atau standar yang dimiliki masing-masing karyawan tersebut. Meaningfulness pada penelitian ini menggunakan indikator:

1. Pekerjaan karyawan yang dilakukan merupakan hal yang penting bagi dirinya. Hal ini sudah dapat dirasakan bagi karyawan khususnya di departemen kantor depan di Dewi Sinta Hotel.

2. Aktifitas kerja yang dilakukan karyawan di hotel secara pribadi berarti bagi dirinya.

3. Pekerjaan yang karyawan lakukan sesuai dengan idealisme karyawan, mengingat sebagian besar karyawan Dewi Sinta Hotel memiliki idealism bekerja di hotel.

b) Variabel Competence

Competence memiliki arti bahwa seorang karyawan yakin dengan kemampuan yang dimilikinya untuk melaksanakan tugas atau pekerjaan sesuai dengan skill yang dimilikinya. Competence pada penelitian ini menggunakan indikator:

1. Karyawan mampu menyelesaikan tugas dengan jangka waktu yang telah ditentukan. Hal ini cukup cocok di hotel Dewi Sinta mengingat mereka cenderung dapat menyelesaikan tugas tepat waktu.

2. Karyawan menguasai keterampilan yang diperlukan untuk melakukan pekerjaannya. Para karyawan direkrut dari sekolah perhotelan ternama sehingga dipastikan memiliki kompetensi sesuai pekerjaannya.

3. Karyawan memiliki kepercayaan diri terhadap kemampuan yang dimilikinya untuk menyelesaikan pekerjaan. Di mana karyawan selalu percaya diri di dalam bekerja, menyambut tamu hotel, hingga dalam menerima keluhan pelanggan. 


\section{c) Variabel Self-determination}

Self-determination berarti karyawan memiliki wewenang dalam memprakarsai atau mengatur segala tindakannya dalam melakukan pekerjaan. Self-determination pada penelitian ini menggunakan indicator sebagai berikut.

1. Karyawan memiliki keleluasaan dalam menentukan bagaimana ia menyelesaikan pekerjaannya. Dengan kata lain, karyawan di Hotel Dewi Sinta diberi keleluasaan dalam menarik sebuah keputusan.

2. Karyawan mempunyai kesempatan untuk menggunakan inisiatif dalam melaksanakan pekerjaan. Hal ini cukup belum terasa di Dewi Sinta, di mana inisiatif seringkali datang dari pihak atasan.

3. Karyawan mempunyai peluang untuk tidak bergantung kepada atasan dalam melaksanakan pekerjaannya. Kemandirian karyawan di Dewi Sinta Hotel patut kembali dipertanyakan sebab mereka cukup sering membuat pertanyaan kepada atasan dalam penyelesaian pekerjaan.

d) Variabel Impact

Impact berarti seberapa besar pengaruh hasil pekerjaan yang dilakukan seorang karyawan di dalam sebuah lingkungan kerja. Impact pada penelitian ini menggunakan indikator:

1. Karyawan mempunyai pengaruh yang besar terhadap keberhasilan pekerjaan di departemennya. Saat ini seluruh karyawan memberi andil cukup besar pada sukses tidaknya operasional di Dewi Sinta Hotel.

2. Hasil kerja karyawan berdampak pada sistem perusahaan. Sistem di Dewi Sinta Hotel sudah berjalan baik, meskipun masih perlu ditingkatkan lebih lanjut. 
3. Opini yang diberikan karyawan menjadi bahan pertimbangan dalam pengambilan keputusan departemen. Opini karyawan Dewi Sinta Hotel tetap diperhatikan, meskipun bukan menjadi alat kunci pengambilan keputusan.

e) Variabel Dynamic structural framework

Dynamic structural framework berarti dimana perusahaan menyediakan sebuah pedoman (guidelines) yang kemudian dapat disesuaikan untuk karyawan. Dynamic structural framework pada penelitian ini menggunakan indikator:

1. Perusahaan menyediakan informasi mengenai apa yang ingin dikerjakan oleh perusahaan di masa yang akan datang.

2. Perusahaan menyediakan informasi tentang bagaimana cara untuk meraih goal atau tujuan perusahaan.

3. Perusahaan menyediakan pedoman untuk menyelesaikan tugas karyawan dengan baik.

4. Karyawan dapat memodifikasi pedoman dalam mengambil keputusan.

5. Karyawan dilibatkan dalam pembentukan visi perusahaan.

6. Karyawan dilibatkan dalam pembentukan misi perusahaan.

f) Variabel Control of workplace decisions

Control of workplace decisions berarti karyawan mendapatkan kesempatan untuk memberikan masukan didalam semua aspek karir professional mereka. Control of workplace decisions pada penelitian ini menggunakan beberapa indicator, yaitu:

1. Karyawan dapat memberikan masukan pembentukan program untuk pengembangan skill karyawan. Program pengembangan skill masih 
belum dilakukan, sehingga perlu melibatkan pihak ketiga baik akademisi maupun lembaga pelatihan.

2. Karyawan dapat memberikan masukan dalam hal mempekerjakan karyawan baru. Keberadaan karyawan sebagai sumber referensi perekrutan karyawan baru cukup dilihat.

3. Karyawan mempunyai keleluasaan dalam mengambil cuti mereka. Saat ini pihak manajemen hotel memberikan kebebasan pengambilan hak cuti, selama tidak berbenturan dengan tingkat okupansi hunian.

4. Karyawan dapat memberikan pendapat dalam mengubah kebijakan perusahaan. Pemberian kesempatan menyalurkan pendapat diberikan saat General Staff Meeting, oleh pihak manajemen Dewi Sinta Hotel.

g) Variabel Fluidity in information sharing

Fluidity in information sharing berarti informasi yang menyangkut perusahaan dan dapat diakses oleh semua individu yang tergabung dalam perusahaan tersebut. Fluidity in information sharing pada penelitian ini menggunakan indikator: 1. Perusahaan memiliki cara yang efisien untuk

menyebarkan informasi kepada seluruh tingkat hirarki perusahaan.

1. Perusahaan memliki cara yang efektif untuk menyebarkan informasi kepada seluruh tingkat hirarki perusahaan. Saat ini penyebaran informasi dilakukan melalui media sosial maupun media komunikasi whatsapp. Metode ini cenderung cukup efektif bagi sebuah penyebaran sebuah kebijakan.

2. Perusahaan menyediakan informasi kepada karyawan mengenai customer. Setiap harinya, duty manager akan menyampaikan informasi perihal kedatangan dan kepergian tamu, hingga tingkat hunian kamar di Dewi Sinta Hotel. 
3. Perusahaan menyediakan akses kepada sumber informasi yang dibutuhkan karyawan dalam menyelesaikan pekerjaan. Akses sumber informasi ditempel di media baik di kantor kepegawaian maupun akses lainnya.

\subsection{TURN OVER INTENTION}

Employee Turnover Intention adalah keinginan dari karyawan untuk keluar dari perusahaan tempatnya berkerja. Employee turnover intention pada penelitian ini diukur dengan pertanyaan yang dikembangkan dari Lum et.al (1998, pp.305-320), Hom dan Griffeth (1991) dalam Panggabean (2004) yang meliputi:

a) Keinginan mencari pekerjaan di bidang yang sama di perusahaan lainnya.

Karyawan di Dewi Sinta Hotel cenderung tidak akan mudah untuk mencari pekerjaan baru di hotel lain. Hal ini disebabkan adanya bentuk pemberdayaan karyawan yang dilakukan secara intensif, baik oleh pemilik, manajemen, maupun penyelia, di tingkat organisasi yang terdapat di Dewi Sinta Hotel.

b) Keinginan mencari pekerjaan baru di bidang yang berbeda.

Hasil dari penelitian menunjukkan bahwa karyawan di Dewi Sinta Hotel masih ingin mencoba bentuk pekerjaan baru di luar industri perhotelan. Beberapa karyawan menyebutkan bahwa mungkin saja mereka akan berpindah profesi yang masih terkait di bidang industri perhotelan, seperti konsultan ataupun tenaga pendidik. Sebagian dari mereka ada yang berniat untuk tidak ingin berlama-lama di industri perhotelan, dan berkeinginan untuk mencoba jenis pekerjaan lainnya di bidang pelayanan. 
c) Keinginan untuk mencari profesi baru

Selama bekerja di Dewi Sinta Hotel, banyak di antara para karyawan masing berkeinginan untuk kembali ke profesi orang tua mereka, yaitu berdagang dan menjadi petani di sawah. Hal ini cukup wajar mengingat sebagian besar karyawan hotel masih memiliki lahan untuk melakukan aktivitas lainnya di luar pekerjaan di hotel.

d) Adanya pemikiran untuk meninggalkan pekerjaan.

Banyak di antara karyawan yang merasa bahwa beban untuk bekerja di hotel cukup berat. Dengan demikian, mereka berpikir untuk mencoba meninggalkan pekerjaan yang mereka sudah geluti bertahuntahun. Beberapa tekanan yang cukup sering muncul bisa datang dari pelanggan (mayoritas), lalu kemudian dari para atasan, kebijakan yang sering berubah, hingga sesama karyawan.

e) Karyawan telah mengevaluasi kerugian yang diakibatkan jika keluar dari pekerjaan.

Adanya turnover intention yang cukup rendah di Dewi Sinta belakangan ini diakibatkan bahwa karyawan tidak berani keluar karena mereka belum mampu menanggung biaya hidup apabila keluar dari pekerjaan. Beberapa dari karyawan senior tetap ingin bertahan di hotel ini, sebab mereka telah melakukan kalkulasi adanya kerugian yang cukup besar apabila mereka keluar dari pekerjaan yang sekarang.

f) Karyawan memiliki kemungkinan untuk pindah pekerjaan pada waktu yang akan datang.

Meskipun pada beberapa departemen, hampir tidak ditemukan kemungkinan pindah pekerjaan dalam waktu dekat, namun karyawan pada departemen yang lain tetap memberikan pendapat kemungkinan mereka pindah bekerja, baik atas alasan keluarga maupun atas alasan profesionalisme. 
Meskipun demikian, hasil dari penelitian menyebutkan bahwa persepsi employee empowerment berpengaruh terhadap turnover intention. Selain itu, terdapat hubungan yang kuat antara persepsi employee empowerment dan turnover intention. Employee empowerment yang dilakukan oleh Dewi Sinta Hotel secara simultan mampu mengurangi keinginan karyawan untuk keluar dari perusahaan. Terdapat dua variabel persepsi employee empowerment yang tidak signifikan berpengaruh terhadap keinginan karyawan untuk keluar dari perusahaan yaitu: competence dan fluidity in information sharing. Adapun faktor meaningfulnees, self- determination, impact, dynamic structural framework, control of workplace decisions secara parsial signifikan berpengaruh terhadap keinginan karyawan untuk keluar dari perusahaan. Berdasarkan pada hasil pengolahan data yang dilakukan, faktor meaningfulness merupakan faktor paling dominan berpengaruh terhadap turnover intention.

\section{PENUTUP}

Berdasarkan hasil observasi dan pembahasan. Maka kesimpulan dari penelitian ini adalah:

a) Persepsi employee empowerment berpengaruh terhadap turnover intention.

b) Terdapat hubungan yang kuat antara persepsi employee empowerment dan turnover intention.

c) Employee empowerment yang dilakukan oleh Dewi Sinta Hotel secara simultan mampu mengurangi keinginan karyawan untuk keluar dari perusahaan.

d) Terdapat dua variabel persepsi employee empowerment yang tidak signifikan berpengaruh terhadap keinginan karyawan untuk keluar 
dari perusahaan yaitu: competence dan fluidity in information sharing. Adapun faktor meaningfulnees, self- determination, impact, dynamic structural framework, control of workplace decisions secara parsial signifikan berpengaruh terhadap keinginan karyawan untuk keluar dari perusahaan.

e) Berdasarkan pada hasil pengolahan data yang dilakukan, faktor meaningfulness merupakan faktor paling dominan berpengaruh terhadap turnover intention.

Selain itu, saran yang diajukan untuk penelitian ini adalah:

a) Dewi Sinta Hotel sebaiknya lebih memberikankepercayaan kepada karyawan agar dalam melaksanakan pekerjaan agar tidak bergantung kepada atas.

b) Perusahaan sebaiknya lebih mengoptimalkan setiap briefing dan rapat-rapat yang dilakukan pada setiap bagian untuk mengetahui opini yang diberikan oleh karyawan.

c) Perusahaan memberikan kesempatan yang sama kepada karyawan agar dapat memodifikasi pedoman misalnya dalam pembuatan keputusan yang berhubungan dengan lingkungan kerja yang telah disediakan oleh perusahaan. Perusahaan lebih melibatkan karyawan dalam pembentukan visi dan misi perusahaan.

d) Perusahaan memberikan kesempatan kepada karyawan untuk memberikan masukkan dalam semua aspek karir profesional karyawan.

e) Variabel fluidity in information sharing memiliki nilai rata-rata sedang, karena itu walaupun tidak signifikan terhadap turnover intention, peneliti merasa perlu memberi saran kepada perusahaan agar dapat meningkatkan fluidity in information sharing yaitu dengan cara menyediakan akses kepada sumber informasi yang dibutuhkan 
karyawan dalam menyelesaikan pekerjaan serta lebih terbuka terhadap karyawan mengenai informasi-informasi yang menyakut functioning perusahaan.

Perusahaan sebaiknya menemukan cara yang lebih efisien lagi dalam menyebarkan informasi kepada seluruh tingkat hirarki. Misalnya dengan menciptakan sebuah program komputer yang berfungsi seperti email (intranet) yang hanya digunakan untuk membagi informasi-informasi penting perusahaan. Setiap karyawan, sebelum memulai pekerjaannya di pagi hari, diwajibkan untuk mengetahui informasi terbaru dari perusahaan. Dan untuk karyawan operasional, sebaiknya supervisor dari setiap departemen operasional mengeceknya, kemudian sebelum memulai pekerjaan memberikan briefing kepada karyawan operasional mengenai informasi terbaru dari perusahaan. Pelatihan yang dapat mempertajam pemahaman karyawan tentang employee empowerment perlu diadakan agar dapat lebih meningkatkan dampak dari penyelenggaraan employee empowerment lebih lanjut.

\section{DAFTAR PUSTAKA}

Conger, J. A., \& Kanungo, R. N. (1988). The empowerment process: Integrating theory and practice. Academy of Management Review. 13, 471-482.

Gibson, Ivancevich, Donnely (1985). Organisasi. Jilid 1. (5th ed.). Jakarta: Erlangga.

Harnoto. (2002). Manajemen sumber daya manusia (2nd ed.). Jakarta: PT. Prenhallindo.

Handoyo, R. (1987). Hubungan keikatan terhadap perusahaan dengan kepuasaan kerja, absensi dan intensi turnover karyawan pada PT. Busana Rama Textil dan Garment di Tange- rang Jawa Barat. Unpublished undergraduate thesis, Fakultas Psikologi Universitas Gajah Mada, Yogyakarta.

Hom, P.W \& Griffeth, R.W. (1991). Structural equation modelling test of a turnover theory: Cross-sectional and longitudinal analysis. Journal of Applied Psychology. 76(3), 350-366. 
Kazlauskaite, R., Buciuniene, I., dan Turauskas, L. (2006). Building employee commitment in the hospitality industry. Baltic Journal of Mana- gement, 1(3), 300. Retrieved December 23, 2008, from http://proquest.umi.com/pqdweb?did $=1138782801 \&$ sid=2\&Fmt $=$ $3 \&$ clientId=20 901\&RQT =309\&VName=PQD.

Lashley, C. (2001). Empowerment: HR strategies for service excellence. Oxford: Butterworth Heine- mann.

Ross, Darren L. (1999). HRN in tourism \& hospitality. New York: Cassel.

Light, J.N. (2004). The relationships and effects of employee involvement, employee empower- ment, and employee satisfaction by job-type in a large manufacturing environment. Capella University. A dissertaation.

Lum L, Kervin J, and Clark K. (1998). Explaining nursing turnover intent: Job satisfaction, pay satisfaction or organizational commitment. Journal of Organizational Behavior. 24, 543- 565.

Luthans, F. (1998). Organizational behaviour (5th ed.). Boston: Irwin.

Matthews, R.A., Diaz, W.M. and Cole, S.G. (2003). The organizational empowerment scale. Personnel Review. 32(3), 297-318. Retrieved December 23, 2008, from ABI/INFORM Global (Proquest) database.

Mello, J. A. (2002). Strategic human resources management. Canada: Thomson Learning.

Mishra, A.K \& Spreitzer, G.M. (1998). Explaining how survivors respond to downsizing the role of trust, empowerment, justice, and work redesign. Academy of Management Review. 23(3), 568-588.

Nedd, N. (2006). Perceptions of empowerment and intent to stay. Nursing Economics. Piman: Jan/Feb 2006, 24(1), 13-19. Retrieved December 23, 2008, from http://proquest. umi.com/ pqdweb?did=995470941\&sid=1\&Fmt=4\&clientId=20901\&RQT $=309 \& \mathrm{VName}=\mathrm{PQD}$.

Panggabean, M. S. (2004). Manajemen sumber daya manusia (2nd ed.). Bogor Selatan: Ghalia Indonesia.

Parasuraman, S. (1989). Nursing turnover: An integrated model. Research in Nursing and Health. 12, 267-277.

Quinn, R.E. and Spreitzer, G.M. (1997). The road to empowerment: Seven questions every leader should consider. Organizational Dynamics. 26(2), 37-49.

Robbins, S. P. (1994). Essentials of organizational behavior (4th ed.). San Diego State University. USA: Prentice-Hall, Inc. 
Roseman, E. (1981). Managing turnover: A positive approach. New York: Amacom.

Salazar, J.P. (2000). The relationship between hospi- tality employee empowerment, overall job satisfaction, and organizational commitment: a study of race and gender differences. Auburn University. A dissertation.

Sanderson, P. A. (2003). The relationship between empowerment and turnover intentions in a structured environment: An assessment of the Navy's Medical Service Corps.Ph.D. disser- tation, Regent University, United States -- Virginia. (Publication No. AAT 3144617). Retrieved April 8, 2009. From www.proquest. com

Spreitzer, G. M. (1995). Psychological empowerment in the workplace: Dimensions, measurement, and validation. Academy of Management Journal. 38(5), 1442-1466. From http://proquest.umi.com/pqdweb?did $=7748688 \&$ Fmt $=4 \&$ clientId $=46969 \&$ $\mathrm{RQT}=309 \& \mathrm{VName}=\mathrm{PQD}$

Spreitzer, G.M. (1997). Toward a common ground in defining empowerment. Research in Orga- nizational Change and Development. 10, 31- 62.

Stewart, A. M. (1998). Empowering people: Pember- dayaan sumber daya manusia. Yogyakarta: Kanisius.

Sugiyono. (2008). Metode penelitian kuantitatif, kualitatif, dan R\&D. Bandung: Alfabeta. Sullivan, J. (2009). The ideal turnover rate. Monster.ca.

Retrieved February 2, 2009, from http://hiring. monster.ca/hr/hr-bestpractices/recruitinghiring-advice/strategicworkforce.../employeet urnover- rate-canada.aspx.

Thomas, K.W. and Velthouse, B.A. (1990). Cognitive elements of empowerment: an 'interpretive' model of intrinsic task motivation. Academy of Management Review. 15(4), 666-81. Retrieved January 23, 2009, from ABI/INFORM Global (Proquest) database.

Thoha, M. (1997). Perilaku organisasi: Konsep dasar dan aplikasinya. Jakarta: PT. Raja Grafindo Persada.

Wilkinson, A. (1988). Empowerment: Theory and practice. Personnel Review. 27(1), 40-56. 


\section{PROFIL PENULIS}

I Gede Sunarjaya, S.Par.,M.Par lahir di Denpasar tanggal 31 Maret 1992 menyelesaikan studi sarjana pariwisata di Universitas Udayana tahun 2014, kemudian melanjutkan studi di Magister Pariwisata Pascasarjana Universitas Udayana dan lulus tahun 2016. Sunarjaya menjadi salah satu pengajar di Elizabeth Internasional dan Dosen di Politeknik Internasional Bali.

Yudha Eka Nugraha, S. Kesos., M. Par lahir di Pati, 04 April 1991 adalah alumnus program S1 Kesejahteraan Sosial Universitas Indonesia, Depok pada tahun 2014. Ia melanjutkan Pendidikan di Magister Pariwisata Universitas Udayana, Denpasar lulus tahun 2018. Yudha memiliki beberapa pengalaman dalam dunia industri seperti sales dan marketing di perusahaan farmasi PT. Darya Varia Laboratoria, Hotel Royal Casa Ganesha. Selain itu ia juga pernah beberapa kali bekerja di lembaga sosial seperti Pertamina Foundation dan Mien R. Uno Foundation sebagai officer program Kewirausahaan 